\title{
Diagnoza i terapia osób dorosłych z zaburzeniami mowy - sprawozdanie z III Łódzkiego Seminarium Logopedycznego
}

W dniu 22 września 2018 roku odbyło się III Łódzkie Seminarium Logopedyczne pt. Diagnoza i terapia osób dorosłych z zaburzeniami mowy, zorganizowane przez Zakład Dialektologii Polskiej i Logopedii Uniwersytetu Łódzkiego. Obrady odbywały się w budynku Wydziału Filologicznego przy ul. Pomorskiej 171/173. Seminarium rozpoczęła oraz słowo wstępne wygłosiła prodziekan ds. dydaktycznych Wydziału Filologicznego UŁ oraz kierownik Zakładu Dialektologii Polskiej i Logopedii dr hab. prof. UŁ Irena Jaros.

Celem wydarzenia było zwrócenie uwagi logopedów, pracowników oświaty i służby zdrowia oraz studentów na to, że logopedia zajmuje się nie tylko diagnozowaniem i terapią dzieci i młodzieży, jak powszechnie jest przyjmowane, ale również dorosłych, często seniorów. Spotkanie stało się okazją do wymiany doświadczeń między praktykującymi logopedami i neurologopedami a studentami studiów licencjackich, magisterskich i podyplomowych oraz sposobnością do uzupełnienia wiedzy i zachętą do zainteresowania się nowymi obszarami badawczymi logopedii.

Łódzkie seminaria logopedyczne cieszą się dużym zainteresowaniem nie tylko logopedów, ale również pracowników oświaty i służby zdrowia. Wrześniowe spotkanie zgromadziło ponad stu uczestników, wśród których znaleźli się przedstawiciele różnych ośrodków naukowych, medycznych, placówek oświatowych z terenu województwa łódzkiego oraz spoza regionu. Prelegenci reprezentowali między innymi

\footnotetext{
* Zakład Dialektologii Polskiej i Logopedii, Instytut Filologii Polskiej i Logopedii, Wydział Filologiczny Uniwersytetu Łódzkiego, ul. Pomorska 171/173, 90-236 Łódź, e-mail: ewelina.zajac@uni.lodz.pl.
} 
Uniwersytet Mikołaja Kopernika w Toruniu, Uniwersytet Łódzki, Prywatny Żłobek „Maluszek” w Kaliszu, Stowarzyszenie Pomocy Osobom Autystycznym „Dalej Razem", Uniwersytecki Szpital Kliniczny im. N. Barlickiego w Łodzi, Wojewódzki Szpital Specjalistyczny im. M. Kopernika w Łodzi, Centrum Onkologii - Instytut im. M. Skłodowskiej-Curie, I Klinikę Radioterapii i Chemioterapii Oddział w Gliwicach, Wielkopolskie Centrum Onkologii, Klinikę Chirurgii Głowy, Szyi i Onkologii Laryngologicznej w Poznaniu.

Seminarium podzielone było na trzy części: dwie wykładowe oraz wykładowo-szkoleniową. Każda z nich kończyła się dyskusją, podczas której chętnie zabierano głos na temat przedstawianych problemów badawczych i terapeutycznych. Dyskusja okazała się doskonałą okazją do wymiany doświadczeń, a wydziałowa aula stała się idealnym miejscem do poszukiwań naukowych rozwiązań na niwie logopedii i neurologopedii. Podczas przerw uczestnicy seminarium mogli zapoznać się z nowym czasopismem logopedycznym wydawanym przez Uniwersytet Łódzki pt. „Logopaedica Lodziensia” oraz uzyskać informacje na temat Łódzkiego Oddziału Polskiego Towarzystwa Logopedycznego, których udzielała jego przewodnicząca dr hab. prof. UŁ Renata Marciniak-Firadza.

Pierwszą część seminarium rozpoczął referat mgr Joanny Himy (Uniwersytecki Szpital Kliniczny im. N. Barlickiego w Łodzi) dotyczący holistycznego podejścia do głosu i jego zaburzeń. Referentka zdefiniowała prawidłowy, zdrowy głos oraz przedstawiła sposoby jak najdłuższego utrzymania go w dobrej kondycji. Opowiedziała także o wpływie gospodarki hormonalnej na głos nastolatka i osoby dorosłej z podziałem na kobiety i mężczyzn. Drugi referat został wygłoszony przez dra Janusza Konopackiego (Wojewódzki Szpital Specjalistyczny im. M. Kopernika w Łodzi), który przedstawił techniki klinicznej interwencji logopedycznej w przypadkach radykalnych zabiegów operacyjnych w obrębie twarzoczaszki. Dr Konopacki zwrócił szczególną uwagę na trudną pracę z pacjentem dorosłym, przynoszącą jednak wymierne efekty dzięki systematycznemu współdziałaniu logopedy i pacjenta. Opowiedział także o prowadzonym przez siebie pacjencie oraz zastosowanych metodach logopedycznych wykorzystanych przez niego podczas terapii. Kolejny wykład, o zbliżonej tematyce, wygłoszony przez dr Agnieszkę Hamerlińską (Uniwersytet Mikołaja Kopernika w Toruniu), dotyczył strategii postępowania logopedycznego w przypadku usunięcia krtani. Referentka przedstawiła wyniki swoich badań przeprowadzonych w grupie pacjentów po tracheotomii, które poparła nagraniami wideo. Ostatni wykład w tej części został wygłoszony przez mgr Annę Stępniak (Prywatny Żłobek „Maluszek” w Kaliszu), absolwentkę Uniwersytetu Łódzkiego, która zaprezentowała doniesienia z badań własnych na temat zaburzeń żucia i połykania u osób dorosłych. Referentka przeprowadziła badania diagnostyczne wśród podopiecznych Domu Pomocy Społecznej w Kaliszu. Podczas wystąpienia mgr Stępniak zaprezentowała szczegółowe dane z diagnozy pacjentów oraz rozmów przeprowadzonych z rodzinami i opiekunami w DPS.

Druga część spotkania zaczęła się od wykładu mgr Izabeli Buczyńskiej (Centrum Onkologii - Instytut im. M. Skłodowskiej-Curie, I Klinika Radioterapii 
i Chemioterapii, Oddział w Gliwicach) poświęconego odczynowi popromiennemu u chorych na nowotwory regionu głowy i szyi w diagnozie i terapii logopedycznej. Referentka zwróciła uwagę, że radioterapia, która przyczynia się do niszczenia komórek nowotworowych, prowadzi także do popromiennych poparzeń skóry w obrębie głowy i szyi, które z kolei wpływają na jakość i komfort mówienia. Podobną tematykę zaprezentowała w swoim wystąpieniu mgr Dominika Kozłowska-Wojnar (Wielkopolskie Centrum Onkologii, Klinika Chirurgii Głowy, Szyi i Onkologii Laryngologicznej). Oprócz wykładu poświęconego rehabilitacji onkologopedycznej pacjentów po leczeniu nowotworów jamy ustnej referentka przedstawiła prezentację z wieloma fotografiami pacjentów, na przykład po usunięciu części języka i jego rekonstrukcji z wolnego płata z przedramienia czy po usunięciu żuchwy. Referentka podkreśliła, że rekonstrukcja nigdy nie daje pełnej sprawności narządów, niezbędna jest pomoc logopedy, który często szuka pomysłów na to, by pacjent w sposób jak najbardziej zrozumiały potrafił komunikować się z otoczeniem. Dwa ostatnie referaty wygłoszone zostały przez reprezentantki Zakładu Dialektologii Polskiej i Logopedii Uniwersytetu Łódzkiego. Pierwszy z nich, zaprezentowany przez dr Renatę Gliwę, poświęcony był przydatności testów fluencji słownej w logopedycznej diagnozie osób dorosłych. Dr Gliwa omówiła testy, którymi posługują się neurologopedzi podczas diagnozowania pacjentów z różnymi rodzajami otępienia. Oprócz tego przedstawiła dane $z$ badań fluencji semantycznej i kategorialnej w zaburzeniach występujących u osób dorosłych (np. choroba Alzheimera, choroba Parkinsona, otępienie). Część wykładową zamknęła mgr Justyna Antczak-Kujawin referatem z zakresu gerontologii, dotyczącym metod wspomagających terapię logopedyczną osób z otępieniem alzheimerowskim. Referentka wielokrotnie podkreśliła, że chorzy powinni korzystać z pomocy neurologopedycznej - nie tylko w celu stymulacji językowej, ale również usprawniania takich funkcji, jak pamięć, myślenie czy orientacja w czasie i przestrzeni.

Ostatnia część seminarium przeznaczona była na wykład szkoleniowy poprowadzony przez mgr Katarzynę H. Suchocką i mgr Marzenę Ganczar, które reprezentowały Stowarzyszenie Pomocy Osobom Autystycznym „Dalej Razem” w Zielonej Górze. Na początku referentki scharakteryzowały deficyty występujące w komunikacji werbalnej i niewerbalnej u osób z ASD. Jednak wykład w głównej mierze dotyczył diagnozy kompetencji komunikacyjnej osób $\mathrm{z}$ autyzmem, dlatego podczas wystąpienia zaprezentowany został autorski program diagnostyczny oraz nagrania przedstawiające diagnozę podopiecznych. Mimo że o zaburzeniach ze spektrum autyzmu wiadomo coraz więcej, to jednak nie zabrakło pytań od uczestników seminarium.

Podjęte tematy, wygłoszone referaty oraz przedstawione prezentacje, fotografie i nagrania były powodem ożywionej dyskusji między uczestnikami oraz prelegentami. Liczne pochwały płynące $\mathrm{z}$ ust wszystkich biorących udział w tym wydarzeniu mogą świadczyć o tym, że i następne, IV Łódzkie Seminarium Logopedyczne, będzie cieszyć się równie dużym zainteresowaniem. 